\title{
IDENTIFIKASI JENIS PADA KEJADIAN CETACEA TERDAMPAR DI INDONESIA DENGAN TEKNIK MOLEKULER
}

\section{SPECIES IDENTIFICATION OF STRANDED CETACEANS IN INDONESIA REVEALED BY MOLECULAR TECHNIQUE}

\author{
Ni Luh Astria Yusmalinda ${ }^{1,2}$, Aji Wahyu Anggoro, ${ }^{1,2}$, Dio Maulid Suhendro ${ }^{3}$, I Made Jaya \\ Ratha $^{4,5}$, Dwi Suprapti ${ }^{6}$, Danielle Kreb ${ }^{7}$, dan Ni Kadek Dita Cahyani ${ }^{1,2^{*}}$ \\ ${ }^{1}$ Indonesian Biodiversity Research Center, Bali, ${ }^{2}$ Yayasan Bionesia Indonesia, ${ }^{3}$ Fakultas Kedokteran \\ Hewan, Universitas Udayana, ${ }^{4}$ Cetacean Sirenian Indonesia, ${ }^{5}$ Whale Stranding Indonesia, ${ }^{6} \mathrm{WWF}$ \\ Indonesia, ${ }^{7}$ Yayasan Konservasi RASI, KALTIM; *E-mail: ditacahyani@ibrc-bali.org
}

\begin{abstract}
Stranding cases of cetaceans in Indonesia including whales, dolphins, and porpoises have recently increasingly become unfold and handled by many people. According to data from Whale Stranding Indonesia (WSI), there have been 40 stranding cases in different parts of Indonesia from early 2016 until February 2017. One of the major obstacles for the people who are handling strandings is to identify the species based on morphology alone when the body is in an advanced stadium of decomposition. WSI recorded that $21 \%$ of the species are unidentifiable. For that reason, this research aims to introduce a molecular genetics approach for identifying stranded cetaceans. Mitochondrial DNA of the gene control region was amplified using a Polymerase Chain Reaction (PCR) method. Sequence data were compared with data from the genebank through percentage overlap. From the 36 individuals, which have been used in this research, 26 amplified sampels had base lengths varying between 445-490 base pairs. Molecular methods successfully identified 15 species and 13 genus of Cetacea from different localities in Indonesia. This study shows that molecular genetic techniques can be used as a method to identify species of cetaceans, in particular of stranded individual, which are hard to identify morphologically. The molecular data may complete the genetic database and become a reference for research on genetic diversity among marine mammal populations in Indonesia.
\end{abstract}

Keywords: stranded Cetaceans, Indonesia, species identification, molecular technique

\begin{abstract}
ABSTRAK
Kasus Cetacea atau Paus dan Lumba-lumba terdampar di Indonesia sejak berapa tahun terakhir ini semakin sering terungkap dan ditangani oleh banyak pihak. Data dari Whale Stranding Indonesia (WSI) mencatat 40 kasus Cetacea terdampar di berbagai tempat di Indonesia selama tahun 2016 hingga bulan Februari 2017. Salah satu kendala bagi para penyelamat di lapangan adalah sulitnya mengidentifikasi jenis secara morfologi karena pada beberapa kasus, individu yang terdampar tidak dalam kondisi utuh. WSI mencatat lebih dari $21 \%$ jenis pada kejadian Cetacea terdampar di Indonesia, tidak teridentifikasi. Penelitian ini bertujuan memperkenalkan pendekatan genetika molekuler dalam mengidentifikasi jenis pada Cetacea terdampar. Gen Control Region dari DNA mitokondria diamplifikasi dengan menggunakan metode Polymerase Chain Reaction (PCR). Data sekuen dibandingkan dengan data di genebank dan dilihat persentase kesamaannya. Penelitian ini menggunakan 36 sampel individu dan 26 diantaranya teramplifikasi dengan panjang basa berkisar antara 445-490 bp (base pair). Metode molekuler berhasil mengidentifikasi 15 spesies dan 13 genus Cetacea yang diambil dari beberapa tempat di Indonesia. Studi ini menunjukkan bahwa teknik genetika molekuler dapat dijadikan metode untuk mengidentifikasi jenis dari Cetacea, terutama mamalia terdampar yang sulit untuk diidentifikasi secara morfologi. Data molekuler yang dihasilkan dapat melengkapi database yang ada di Indonesia serta menjadi penunjang bagi penelitian tentang keragaman genetik dan hubungan antar populasi mamalia akuatik di Indonesia.
\end{abstract}

Kata kunci: Cetacea terdampar, Indonesia, penentuan jenis, teknik molekuler 


\section{PENDAHULUAN}

Kasus Cetacea atau paus dan lumbalumba terdampar di Indonesia menjadi perhatian banyak pihak, khususnya pemerhati lingkungan (Priyasidharta, 2016; Iqbal, 2016). Data dari Whale Stranding Indonesia (WSI) (http://www.whalestrandingindonesia. com) mencatat 40 kasus Cetacea terdampar di berbagai tempat di Indonesia selama tahun 2016 hingga bulan Februari 2017. Data juga melaporkan bahwa $78 \%$ kasus Cetacea terdampar berakhir dengan kematian (Gambar 1 dan Gambar 2).

Salah satu kendala bagi para penyelamat Cetacea yang terdampar di lapangan adalah sulitnya identifikasi jenis. Pada beberapa kasus, individu tidak dapat atau susah ditentukan jenisnya secara morfologi, karena hanya sisa tubuh yang tertinggal atau kurangnya dokumentasi misalnya foto ciri spesifik untuk beberapa jenis Cetacea. WSI, mencatat lebih dari $21 \%$ jenis individu pada kejadian Cetacea terdampar di Indonesia, tidak teridentifikasi. Hal ini menjadi catatan penting mengingat identifikasi jenis sangat diperlukan sebagai referensi bagi pendataan dan perlindungan terhadap megafauna akuatik ini. Data yang dikumpulkan dapat menjadi gambaran mengenai detail populasi yang beruaya di perairan Indonesia.

Selain identifikasi secara morfologi, saat ini pendekatan secara molekuler juga dapat dilakukan untuk mengidentifikasi jenis Cetacea yang terdampar (Dalebout et al., 1998; Baker et al., 1996; Baker et al., 2006). Hanya menggunakan sedikit sampel dari jaringan tubuh hewan seperti daging, darah, kulit atau organ dalam, teknik Polymerase Chain Reaction (PCR) dapat mengidentifikasi sekuen DNA yang unik dari jenis yang berbeda dari gen tertentu (Sambrook and Russell, 2001). Teknik ini bahkan telah diaplikasikan untuk mengidentifikasi sirip ikan hiu yang diperdagangkan secara ilegal (Sembiring et al., 2015) atau mislabelling pada daging yang digunakan dalam jenis makanan yang diperjualbelikan, seperti misalnya ikan pada sushi (Willette et al., 2017).

Berdasarkan hal tersebut, penelitian ini bertujuan untuk memperkenalkan pendekatan genetika molekuler dalam identifikasi jenis pada kejadian Cetacea terdampar, baik untuk peneguhan hasil identifikasi yang sudah ada maupun yang sulit dilakukan secara morfologi. Kedepannya, data untuk molekuler yang dikumpulkan dapat menjadi penunjang bagi penelitian tentang keragaman genetik dan hubungan antar populasi dari Cetacea di Indonesia.

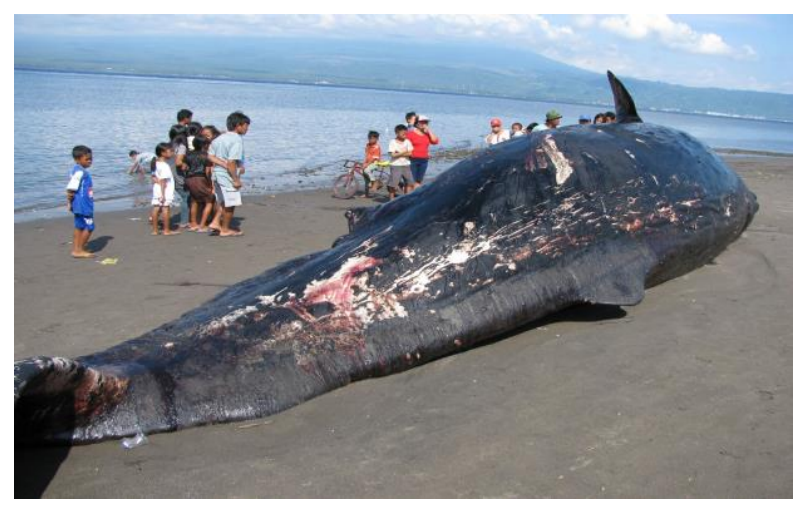

Gambar 1. Paus Sperma terdampar mati di perairan Gilimanuk, Bali pada 27 November 2010. Foto: BKSDA Bali.

\section{METODE PENELITIAN}

Sampel pada penelitian ini berasal dari berbagai sumber (Lampiran 1.) beberapa diantaranya dapat diidentifikasi secara morfologi di lapangan. Sampel diambil dari bagian daging, sebanyak \pm 30 gram. Jaringan diambil dengan scalpel steril, kemudian disimpan dalam etanol $70 \%$ sebelum dilakukan extraksi DNA di laboratorium. Metode ekstraksi DNA menggunakan 10\% Chelex (Walsh et al., 1991). DNA hasil ekstraksi diamplifikasi dengan menggunakan metode PCR (Polymerase Chain Reaction) dengan menggunakan primer H16498 (5'- CCTGAA GTAAGAACCAGATG- 3') and L15812 (5'CCTCCCTAAGACTCAAGGAAG- 3') (Rosel et al., 1994). 
PCR dilakukan dalam $25 \mu \mathrm{L}$ reaksi yang terdiri dari $1 \mu \mathrm{L}$ DNA hasil ekstraksi, 2,5 $\mu \mathrm{L}$ 10x PCR buffer (Applied Biosystems), 2,5 $\mu \mathrm{L} 10 \mathrm{mMdNTPs}$, masing-masing $1,25 \mu \mathrm{L}$ primer dengan konsentrasi $10 \mathrm{mM}, 2$ $\mu \mathrm{L} 25 \mathrm{mM} \mathrm{MgCl}_{2}, 0,125 \mu \mathrm{L}$ AmplyTaq $^{\mathrm{TM}}$ (Applied Biosystems) dan 14,5 $\mu \mathrm{L}$ ddH2O. Reaksi dilakukan dalam 38 siklus menggunakan teknik "Hotstart" dengan parameter sebagai berikut: predenaturasi dilakukan pada suhu $80^{\circ} \mathrm{C}$ selama 10 detik dan $94^{\circ} \mathrm{C}$ selama 15 detik, kemudian dilanjutkan dengan tahap denaturasi pada suhu $94^{\circ} \mathrm{C}(30$ detik), penempelan primer atau annealing pada suhu $50^{\circ} \mathrm{C}$ (30 detik), pemanjangan rantai nukleotida atau extension selama 45 detik pada suhu $72^{\circ} \mathrm{C}$ dan siklus pemanjangan untai ganda di akhir amplifikasi selama 5 menit pada suhu $72^{\circ} \mathrm{C}$. Hasil reaksi PCR kemudian divisualisasi dalam $1 \%$ gel agarose yang ditambahkan dengan ethidium bromide. Untai DNA yang dihasilkan dalam reaksi PCR akan berpendar di bawah sinar UV karena ethidium bromide dapat berikatan dengan DNA. Hasil amplifikasi PCR kemudian disekuen di UC Berkeley sequencing facility.

Hasil sekuensing yang berupa untaian DNA dari dua arah, dibaca dengan Geneious 7.1.4 (Kearse et al., 2012) dan disejajarkan (alignment) dengan MUSCLE (Edgar, 2004). Data sekuen kemudian dibandingkan dengan data di genebank dengan BLAST (https:// blast.ncbi.nlm.nih.gov/Blast.cgi) dan dilihat persentase kesamaannya. Pembangunan pohon filogenetik dilakukan dengan MEGA7 (Kumar et al., 2016) menggunakan model Neighbor Joining dengan nilai bootstrap 1000 .

\section{HASIL DAN PEMBAHASAN}

\subsection{Hasil}

Sebanyak 36 sampel individu dalam penelitian ini diamplifikasi dengan metode PCR dan hanya 26 sampel yang berhasil diamplifikasi dan dapat dibandingkan dengan data dari genebank (https://www.ncbi.nlm. nih.gov) dengan accession number KY96 3282-KY963307. Panjang basa yang teramplifikasi berkisar antara 445-490 bp (base pair). Primer yang digunakan untuk mengamplifikasi gen control region dari DNA mitokondria, berhasil mengidentifikasi 15 spesies dan 13 genus Cetacea yang diambil dari beberapa tempat di Indonesia. Hampir semua data morfologi dari sampel yang diidentifikasi di lapangan dapat diverifikasi dengan metode genetik (Lampiran 1.), akan tetapi masih ada sepuluh sampel yang tidak teramplifikasi. Beberapa penyebab sampel tidak dapat teramplifikasi, diantaranya adalah DNA yang sudah terdegradasi pada sampel daging yang telah membusuk atau dipanaskan, atau terhambatnya proses PCR karena tingginya kandungan lemak dari sampel yang diambil dari bagian blubber atau lapisan lemak di bawah kulit.

Pohon filogenetik yang dibuat dari hasil penelitian ini menggambarkan hubungan kekerabatan antar spesies dan juga kedekatan genetik antara sekuen sampel dengan sekuen pembanding dari genebank (Gambar 2.). Sekuen dari penelitin ini mengelompok dalam kelompok atau clade sesuai dengan sekuen pembanding dari genebank. Kedekatan genetik antara hasil dengan sekuen pembanding berkisar antara 0,034 antara Stenella attenuata (lumba-lumba Bintik) dan Stenella longirostris (lumba-lumba Spinner), hingga 0,514 antara Ziphius cavirostris (paus moncong Cuvier) dan Balenoptera omurai (paus Omura). Jarak genetik diantara sekuen yang diidentifikasi sebagai spesies yang sama berkisar antara 0,00-0,022.

\subsection{Pembahasan}

Studi ini telah mengidentifikasi subordo Mysticeti atau Paus Baleen, yaitu Balaenoptera edeni (paus Bryde), Balaenoptera omurai (paus Omura) dan Megaptera novaeangliae (paus Bungkuk) dan sub ordo odontoceti atau jenis Cetacea bergigi, yaitu Physeter macrocephalus paus Sperma, Peponocephala electra (paus Kepala Melon), Orcinus orca (paus Pembunuh), 


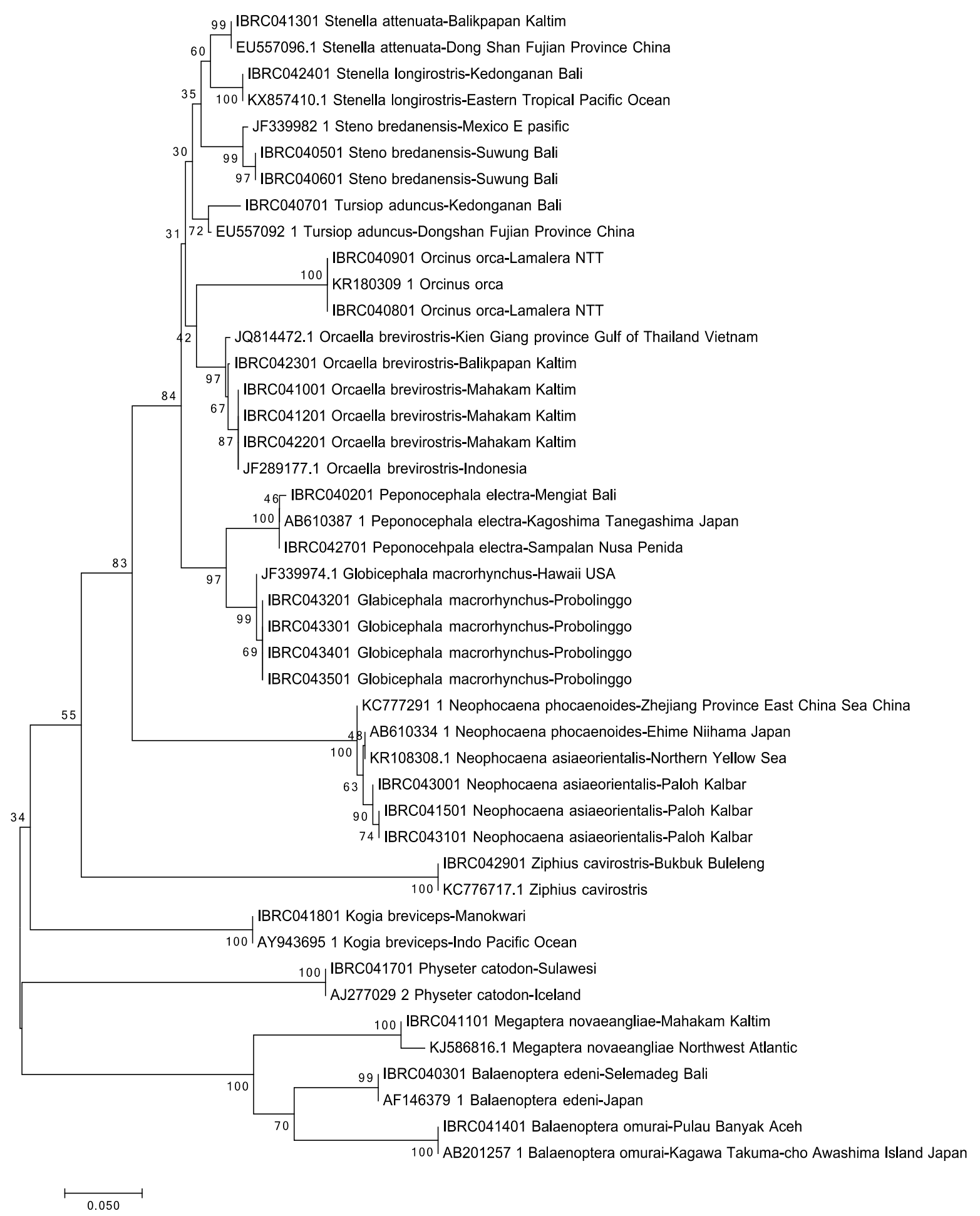

Gambar 2. Pohon filogenetik dengan metode Neighbor-Joining dan bootstrap 1000, dibangun dengan program MEGA 7 (Kumar et al., 2016).

Kogia breviceps (paus Sperma Kerdil), pendek), Stenella longirostris (lumba-lumba Ziphius cavirostris (paus Cuvier), Globi- Spinner), Stenella attenuata (lumba-lumba cephala macrorhynchus (paus Pilot sirip Bintik), Steno bredanensis (lumba-lumba 
bergigi kasar), Orcaella brevirostris (lumbalumba Irrawaddy) dan Neophocaena phocaenoides (porpoise tanpa sirip). Semua jenis tersebut di atas dilindungi oleh UU No. 5, 1990 dan PP No 7, 1999 di Indonesia. Sementara itu berdasarkan IUCN, Pesut Mahakam (lumba-lumba Irrawaddy) termasuk dalam kriteria kritis dan terancam punah (Critically Endangered) dan masuk kedalam CITES Apendiks I (Jefferson et al., 2008). Lumba-lumba Irrawaddy atau Pesut Pesisir dan Porpoise tanpa sirip keduanya terdaftar sebagai vulnerable atau rawan punah dan juga masuk di CITES I sama halnya dengan paus sperma. Jenis lain dalam studi ini terdaftar sebagai Data Deficient atau data tidak tersedia, Not Assessed atau status belum dinilai atau Least Concern atau kurang mengkhwatirkan dan mereka semua masuk didalam CITES appendix II. Khususnya lumba-lumba Irrawaddy dan Porpoise tanpa sirip adalah residen dan menjadikan pesisir yang dangkal sebagai habitat mereka yang rawan dampak kegiatan manusia. Paus sperma juga dianggap sebagai residen di perairan Indonesia, khususnya paus remaja yang sepanjang tahun dapat ditemukan di Indonesia.

Hasil di atas memperlihatkan bahwa data genetik dapat dijadikan pendekatan yang baik, untuk membedakan taxa berdasarkan genus dan spesies. Sebagai contoh, dua sampel dari Tabanan, Bali dan Pulau Banyak, Aceh (IBRC040301 dan IBRC041401) teridentifikasi secara morfologi sebagai Paus Bryde (scientific name) tetapi berdasarkan analisa molekuler kedua sampel tersebut diketahui sebagai Balenoptera edeni (IBRC040301) dan Balenoptera omurai (IBRC041401).

Identifikasi molekuler juga dapat memberikan data tentang keberadaan jenis Cetacea tertentu di perairan Indonesia dan untuk itu ada beberapa hal yang harus diperhatikan dalam membandingkan data sekuen DNA dengan baseline data yang berasal dari genebank (https://www.ncbi. nlm.nih.gov/). Genus Neophocaena pada pe- nelitian ini mengelompok pada satu grup yang sama dengan Neophocaena asiaeorientalis dan Neophocaena phocaenoides dari genebank. Kedua spesies tersebut bahkan memiliki dua sekuen yang identik (AB61 0334 dan KR108308). Hal ini mungkin dikarenakan adanya satu spesies yang sama namun diidentifikasi menjadi dua spesies berbeda dan dinamai menjadi dua nama yang berbeda oleh dua penulis berbeda pada publikasi sebelumnya. Sulitnya menentukan penamaan yang tepat untuk kedua jenis tersebut, membuat penulis mengelompokkan ketiga individu Neophocaena sebagai Neophocaena phocaenoides, karena Neopho caena asiaorientalis saat ini diketahui memiliki penyebaran yang terbatas di Sungai Yangtse.

Spesies lain yang juga menarik untuk dibahas adalah lumba-lumba Irrawaddy. Spesies ini tersebar di perairan pesisir yang dangkal dari India hingga Filipina dan termasuk Indonesia, khususnya daerah muara dan teluk. Diketahui pula ada tiga populasi yang murni hidup di air tawar sepanjang hidupnya di Sungai Ayeyarwady, Mekong dan Mahakam (Beasley et al., 2005). Keempat sampel yang diidentifikasi sebagai lumba-lumba Irrawaddy pada penelitian ini berasal dari dua lokasi berbeda yaitu Sungai Mahakam dan Teluk Balikpapan. Walaupun sama-sama teridentifikasi sebagai lumbalumba Irrawaddy, keempat sampel mengelompok menjadi dua clade berbeda pada pohon filogenetik, yang menunjukkan bahwa terdapat variasi genetik antara keempat sampel. Jika dilihat lebih lanjut, tiga sampel dari Sungai Mahakam mengelompok menjadi satu dan teridentifikasi sebagai haplotype 5 .

Sampel dari Teluk Balikpapan teridentifikasi sebagai haplotype baru yang menjadi sister taxa dari haplotype 5 dan memiliki jarak genetik 0,01 dari sekuen yang ditemukan di Sungai Mahakam. Hasil ini sangat menarik karena menjadi indikasi adanya variasi genetik antara individu dari populasi yang berbeda, dan dapat menjadi dasar bagi penelitian tentang keragaman 
genetik dari dua populasi yang merupakan satwa endemik dan dilindungi di Indonesia. Beasley et al. (2005) bahkan mengidentifikasi satu populasi baru di Australia dengan metode genetik untuk melengkapi identifikasi morfologi yang umumnya digunakan dan kemudian menamai populasi tersebut sebagai spesies baru.

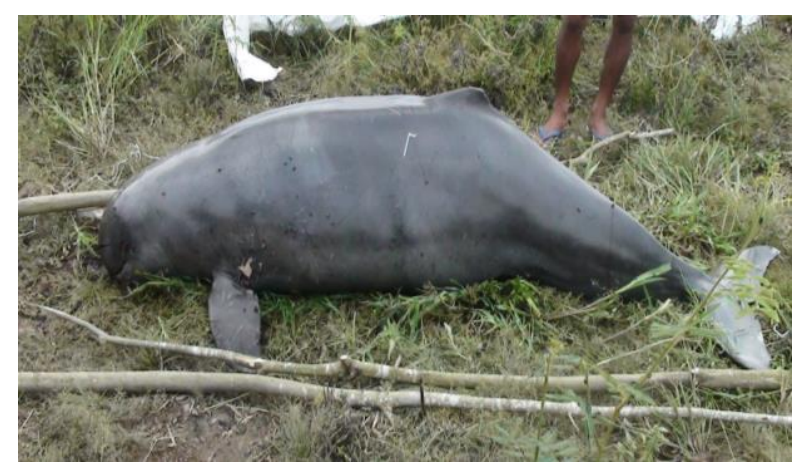

Gambar 3. Pesut terdampar mati pada tanggal 1 November 2009 di Muara Semayang-Pela, Kalimantan Timur. Foto: Budiono/ RASI.

\section{KESIMPULAN}

Studi ini menunjukkan bahwa teknik genetika molekuler dapat dijadikan metode untuk mengidentifikasi jenis dari Cetacea hingga tingkat spesies, terutama bagian tubuh dari mamalia terdampar yang sulit untuk diidentifikasi secara morfologi.

\section{UCAPAN TERIMA KASIH}

Penelitian ini terlaksana dengan dana dari the United States Agency for International Development's "Supporting Universities to Partner across the Pacific" program (Cooperative Agreement No. 497-A-00-1000008-00).

Penulis mengucapkan terima kasih kepada Firman, Imelda Susanti, Budiono, Anne Dawydowa yang melakukan nekropsi dan pengambilan sebagian dari sampel di Kalimantan Timur serta Turtle Guard-FKH, Universitas Udayana yang telah membantu pengambilan sampel di Bali

\section{DAFTAR PUSTAKA}

Baker, C.S., F. Cipriano, and S.R. Palumbi. 1996. Molecular genetic identification of whale and dolphin products from commerical markets in Korea and Japan. Molecular Ecology, 5:671685.

Baker, C.S., V.S. Lukoschek, M.L. Lavery, Dalebout, M. Yong-Un, T. Endo, and N. Funahashi. 2006. Incomplete reporting of whale, dolphin and porpoise "bycatch" revealed by molecular monitoring of Korean markets. Animal Conservation, 9(4):474-482.

Beasley, I., K.M. Robertson, and P. Arnold. 2005. Description of a new dolphin, the Australian snubfin dolphin Orcaella heinsohni sp. (Cetacea, Delphinidae). Marine Mammal Science, 21(3):365-400.

Dalebout, M.L., A. Van Helden, K. Van Waerebeek, and C.S. Baker. 1998. Molecular genetic identification of southern emisphere beaked whales (Cetacea: Ziphiidae). Molecular Ecology, 7:687-694.

Edgar, R.C. 2004. Muscle: Multiple sequence alignment with high accuracy and high throughput. Nucleic Acids Res, 32:1792-1797.

Iqbal, D. 2016. Makin banyak hiu terdampar di Pangandaran. Ada Apa? Dari Flora Fauna, http://www.mongabay.co.id/ 2016/12/05/makin-banyak-mamalialaut-terdampar-di-pangandaran-adaapa/. 5 Desember 2016. [Diunduh pada 26 April 2017].

Jefferson, T.A., L. Karczmarski, D. Kreb, K. Laidre, G. O'Corry-Crowe, R. Reeves, L. Rojas-Bracho, E. Secchi, E. Slooten, B.D. Smith, J.Y. Wang, and K. Zhou. 2008. Orcaella brevirostris (Mahakam River subpopulation). From The IUCN Red List of Threatened Species 2008: e.T3942 8A98842174, (errata version published in 2016), http://www.iucnredlist. 
org/details/39428/0. [Retrieved on 4 August 2017].

Kearse, M., R. Moir, A. Wilson, S. StonesHavas, M. Cheung, S. Sturrock, S. Buxton, A. Cooper, S. Markowitz, C. Duran, T. Thierer, B. Ashton, P. Meintjes, and A. Drummond. 2012. Geneious Basic: An integrated and extendable desktop software platform for the organization and analysis of sequence data. Bioinformatics, 28: 1647-1649.

Kumar, S., G. Stecher, and K. Tamura. 2016. MEGA7: Molecular evolutionary Gene-tics Analysis version 7.0 for bigger datasets. Molecular Biology and Evolution, 33(7):1870-1874.

Priyasidharta, D. 2016 Paus terdampar di Probolinggo, ini kata ahli mamalia laut. https://m.tempo.co/read/news/ 2016/06/16/058780576/paus-terdam par-di-probolinggo-ini-kata-ahli-ma malia-laut. 16 Juni 2016. [Diunduh pada 16 Juni 2016].

Rosel, P.E., A.E. Dizon, and J.E. Heyning. 1994. Genetic analysis of sympatric morphotypes of common dolphins (genus Delphinus). Marine Biology, 119(2):159-167.
Sambrook, J. and D.W. Russell. 2001. Molecular cloning: a laboratory manual. $3^{\text {rd }}$ ed. Cold Spring Harbour Laboratory Press. Cold Spring Harbour. 2100p.

Sembiring, A., N.P.D. Pertiwi, A. Mahardini, R. Wulandari, E.M. Kurniasih, A.W. Kuncoro, N.K.D. Cahyani, A.W. Anggoro, M. Ulfa, H. Madduppa, K.E. Carpenter, P.H. Barber, and G.N. Mahardika. 2015. DNA barcoding reveals targeted fisheries for endangered sharks in Indonesia. Fisheries Research, 164:130-134.

Walsh, P., D.A. Metzger, and R. Higuchi. 1991. Chelex-100 as a medium for simple extraction of DNA for PCR based typing from forensic material. Biotechniques, 10:506-513.

Willette, D.A., S.E. Simmonds, S.H. Cheng, S. Esteves, T.L. Kane, H. Nuetzel, N. Pilaud, R. Rachmawati, and P.H. Barber. 2017. Using DNA barcoding to track seafood mislabeling in Los Angeles restaurants. Conservation Biology, 2:1-23.

$\begin{array}{ll}\text { Diterima } & : 29 \text { April } 2017 \\ \text { Direview } & : 16 \text { Mei } 2017 \\ \text { Disetujui } & : 2 \text { November } 2017\end{array}$


Lampiran 1.

\begin{tabular}{|c|c|c|c|c|c|c|c|c|c|c|c|}
\hline \multirow[b]{2}{*}{ No } & \multirow[b]{2}{*}{ ID sampe1 } & \multirow[b]{2}{*}{$\begin{array}{l}\text { Tanggal } \\
\text { koleksi }\end{array}$} & \multirow[b]{2}{*}{ Kolektor } & \multirow[b]{2}{*}{$\begin{array}{l}\text { Hasil } \\
\text { PCR }\end{array}$} & \multirow[b]{2}{*}{ Lokasi } & \multirow[b]{2}{*}{$\begin{array}{l}\text { Identifi } \\
\text { keasi } \\
\text { secara } \\
\text { morfol } \\
\text { ogi }\end{array}$} & \multicolumn{5}{|c|}{ Perbandingan dengan data Genebank (NCBI) } \\
\hline & & & & & & & $\begin{array}{l}\text { Spesies } \\
\text { terdekcat }\end{array}$ & $\begin{array}{c}\text { Status } \\
\text { Konserva } \\
\text { IUi } \\
\text { TESCI } \\
\text { TES }\end{array}$ & $\begin{array}{l}\text { \% } \\
\text { kesam } \\
\text { aan } \\
\text { secara } \\
\text { gene- } \\
\text { tik }\end{array}$ & $\begin{array}{l}\text { Asal } \\
\text { sampe1 }\end{array}$ & $\begin{array}{l}\text { Genbank } \\
\text { Acce- } \\
\text { ssion } \\
\text { Number }\end{array}$ \\
\hline 1 & $\begin{array}{l}\text { IBRCOA } \\
101\end{array}$ & $\begin{array}{l}12 \text { Mei } \\
2010\end{array}$ & $\begin{array}{l}\text { I Made Jayra } \\
\text { Ratha }\end{array}$ & - & $\begin{array}{l}\text { Sheraton, } \\
\text { Nusa Duaa } \\
\text { Bali D }\end{array}$ & Paus & - & & - & - & - \\
\hline 2 & IBRC & $\begin{array}{l}10 \text { Aggustus } \\
2010\end{array}$ & $\begin{array}{l}\text { I Made Jaya } \\
\text { Ratha }\end{array}$ & + & $\begin{array}{l}\text { Mengiat, } \\
\text { Nusa Dua, } \\
\text { Bali }\end{array}$ & $\begin{array}{l}\text { Paus } \\
\text { kepala } \\
\text { melon }\end{array}$ & $\begin{array}{l}\text { Peponacepha } \\
\text { Za electra } \\
\text { (Pavis kepala } \\
\text { melon) }\end{array}$ & $\mathrm{IC} /-$ & $99 \%$ & $\begin{array}{l}\text { Kagoshi } \\
\text { mainegas } \\
\text { Tameasas } \\
\text { Jimap }\end{array}$ & $\begin{array}{l}\mathrm{AB} 6103 \\
\mathrm{~S} 7{ }_{1}\end{array}$ \\
\hline 3 & IBRC & $\begin{array}{l}13 \text { Agustus } \\
2010\end{array}$ & $\begin{array}{l}\text { I Made Jaya } \\
\text { Ratha }\end{array}$ & + & $\begin{array}{l}\text { Selemade } \\
\text { gemanan, } \\
\text { Babli }\end{array}$ & $\begin{array}{l}\text { Paus } \\
\text { Bryde }\end{array}$ & $\begin{array}{l}\text { Balaremoptera } \\
\text { edení (Paus } \\
\text { Bryde) }\end{array}$ & DSICIT & $100 \%$ & Japan & $\mathrm{AF}_{\mathrm{S} 14637}$ \\
\hline 4 & $\begin{array}{l}\text { IBRC } \\
040401\end{array}$ & $\begin{array}{l}27 \\
\text { November } \\
2010\end{array}$ & $\begin{array}{l}\text { I Made Jaya } \\
\text { Ratha }\end{array}$ & - & $\begin{array}{l}\text { Gilimanul:- } \\
\text { Jembrana, } \\
\text { Balii }\end{array}$ & $\begin{array}{l}\text { Paus } \\
\text { sperma }\end{array}$ & - & & - & - & - \\
\hline 5 & $\begin{array}{l}\text { IBREC } \\
040501\end{array}$ & $\begin{array}{l}12 \text { Januari } \\
2011\end{array}$ & $\begin{array}{l}\text { I Made Jaya } \\
\text { Ratha }\end{array}$ & + & $\begin{array}{l}\text { Pantai } \\
\text { Suvvung, } \\
\text { Bali }\end{array}$ & $\begin{array}{l}\text { I-umba } \\
\text { bergigi } \\
\text { 1casar }\end{array}$ & $\begin{array}{l}\text { Steno } \\
\text { bredanensis } \\
\text { (ILumba } \\
\text { bergigi kasar) }\end{array}$ & $\mathbf{L C} /-$ & $99 \%$ & $\begin{array}{l}\text { Mexico, } \\
\text { Pasific } \\
\text { Pasif }\end{array}$ & $\begin{array}{l}\text { JF } 339998 \\
2-1\end{array}$ \\
\hline 6 & $\begin{array}{l}\text { IBRC } \\
040601\end{array}$ & $\begin{array}{l}\text { 12 Januari } \\
2011\end{array}$ & $\begin{array}{l}\text { I Made Jaya } \\
\text { Ratha }\end{array}$ & + & $\begin{array}{l}\text { Pantai } \\
\text { Suwung, } \\
\text { Bali }\end{array}$ & $\begin{array}{l}\text { Lumba } \\
\text { bergigi } \\
\text { kasar }\end{array}$ & $\begin{array}{l}\text { Steno } \\
\text { bredanensis } \\
\text { (Lumba } \\
\text { bergigi kasar) }\end{array}$ & $\mathbf{L C} /-$ & $99 \%$ & $\begin{array}{l}\text { Mexico, } \\
\text { E. } \\
\text { Pasific }\end{array}$ & $\begin{array}{l}\text { JF33998 } \\
2 \_1\end{array}$ \\
\hline 7 & $\begin{array}{l}\text { IBRC } \\
040701\end{array}$ & $\begin{array}{l}13 \text { Januari } \\
2011\end{array}$ & $\begin{array}{l}\text { I Made Jaya } \\
\text { Ratha }\end{array}$ & + & $\begin{array}{l}\text { Kedongan } \\
\text { an, Bali }\end{array}$ & $\begin{array}{l}\text { Lumba } \\
\text { hidung } \\
\text { botol } \\
\text { Indo- } \\
\text { Pasifik }\end{array}$ & $\begin{array}{l}\text { Tidrsiops } \\
\text { aduncus } \\
\text { (Lumba } \\
\text { hidung boto } 1 \\
\text { Indo-Pasifik) }\end{array}$ & $\mathrm{DD} /-$ & $97 \%$ & $\begin{array}{l}\text { Dongsha } \\
\text { n, Fujian } \\
\text { Province } \\
\text {, China }\end{array}$ & $\begin{array}{l}\text { EUS5570 } \\
92 \_1\end{array}$ \\
\hline 8 & $\begin{array}{l}\text { IBRC } \\
040801\end{array}$ & S Mei 2011 & Paul Barber & + & $\begin{array}{l}\text { Lamalera, } \\
\text { NTT }\end{array}$ & $\begin{array}{l}\text { Paus } \\
\text { permbu } \\
\text { nuh }\end{array}$ & $\begin{array}{l}\text { Orcinus orca } \\
\text { (Paus } \\
\text { pembunuh) }\end{array}$ & $\mathrm{DD} /-$ & $100 \%$ & - & $\begin{array}{l}\text { KR1803 } \\
\text { O9_1 }\end{array}$ \\
\hline 9 & $\begin{array}{l}\text { IBRC } \\
040901\end{array}$ & S Mei 2011 & Paul Barber & + & $\begin{array}{l}\text { Lamalera, } \\
\text { NTT }\end{array}$ & $\begin{array}{l}\text { Paus } \\
\text { pembu } \\
\text { nuh }\end{array}$ & $\begin{array}{l}\text { Orcinus orca } \\
\text { (Paus } \\
\text { pembunuh) }\end{array}$ & $\mathrm{DD} /-$ & $100 \%$ & - & $\begin{array}{l}\text { KRR1803 } \\
09 \_1\end{array}$ \\
\hline 10 & $\begin{array}{l}\text { IBRC } \\
041401\end{array}$ & $\begin{array}{l}\text { 18 Maret } \\
2013\end{array}$ & Maria U1fa & + & $\begin{array}{l}\text { Pulau } \\
\text { Banyak, } \\
\text { Aceh }\end{array}$ & $\begin{array}{l}\text { Paus } \\
\text { Bryde }\end{array}$ & $\begin{array}{l}\text { Balaenoptera } \\
\text { omurai (Paus } \\
\text { Omura) }\end{array}$ & $\begin{array}{l}\mathrm{DD} / \mathrm{CIT} \\
\mathrm{ES} \mathrm{I}\end{array}$ & $100 \%$ & $\begin{array}{l}\text { Kagawa } \\
\text { Takuma- } \\
\text { cho, } \\
\text { Awashi } \\
\text { ma } \\
\text { Island, } \\
\text { Japan }\end{array}$ & $\begin{array}{l}\mathrm{AB} 2012 \\
57 \_1\end{array}$ \\
\hline 11 & $\begin{array}{l}\text { IBRC } \\
041501\end{array}$ & $\begin{array}{l}28 \\
\text { November } \\
2014\end{array}$ & $\begin{array}{l}\text { Dwi Suprapti } \\
\text { (WWF) }\end{array}$ & + & $\begin{array}{l}\text { Paloh, } \\
\text { Kalimanta } \\
\text { n Barat }\end{array}$ & $\begin{array}{l}\text { Porpois } \\
\text { e tanpa } \\
\text { sirip }\end{array}$ & $\begin{array}{l}\text { Neophocaena } \\
\text { phocaenoides } \\
\text { (Porpoise } \\
\text { tanpa sirip) }\end{array}$ & $\begin{array}{l}\mathrm{VU} / \mathrm{CIT} \\
\mathrm{ES} \mathrm{I}\end{array}$ & $99 \%$ & $\begin{array}{l}\text { Zhejiang } \\
\text { Province } \\
\text { East } \\
\text { China } \\
\text { Sea, } \\
\text { China }\end{array}$ & $\begin{array}{l}\text { KC7772 } \\
91 \_1\end{array}$ \\
\hline
\end{tabular}




\begin{tabular}{|c|c|c|c|c|c|c|c|c|c|c|c|}
\hline 12 & $\begin{array}{l}\text { IBRCO41 } \\
701\end{array}$ & Tahun 2014 & $\begin{array}{l}\text { Sekar Mira } \\
\text { (LIPI) }\end{array}$ & + & Sulawesi & $\begin{array}{l}\text { Paus } \\
\text { sperma }\end{array}$ & $\begin{array}{l}\text { Physeter } \\
\text { macrocephal } \\
\text { us (Pans } \\
\text { sperma) }\end{array}$ & $\begin{array}{l}\mathrm{VU/CIT} \\
\mathrm{ESI}\end{array}$ & $100 \%$ & Iceland & $\begin{array}{l}\text { A } 27702 \\
9 \_2\end{array}$ \\
\hline 13 & $\begin{array}{l}\text { IBRCO41 } \\
\text { SO1 }\end{array}$ & $\begin{array}{l}14 \\
\text { November } \\
2013\end{array}$ & $\begin{array}{l}\text { Andri Wahyu } \\
\text { Kuncoro }\end{array}$ & + & $\begin{array}{l}\text { Manokwar } \\
\text { i, Papua } \\
\text { Barat }\end{array}$ & $\begin{array}{l}\text { Paus } \\
\text { sperma } \\
\text { kerdi1 }\end{array}$ & $\begin{array}{l}\text { Kogia } \\
\text { breviceps } \\
\text { Parus sperma } \\
\text { kerdil) }\end{array}$ & $\mathbf{D D} /-$ & $100 \%$ & $\begin{array}{l}\text { Indo } \\
\text { Pacific } \\
\text { Ocean }\end{array}$ & $\begin{array}{l}\text { AY9436 } \\
95 \_1\end{array}$ \\
\hline 14 & $\begin{array}{l}\text { IBRCO42 } \\
401\end{array}$ & $\begin{array}{l}\text { O4 } \\
\text { November } \\
2015\end{array}$ & Ratna/Icha & + & $\begin{array}{l}\text { Kedongan } \\
\text { an, Bali }\end{array}$ & $\begin{array}{l}\text { Lumba } \\
\text { spinner }\end{array}$ & $\begin{array}{l}\text { Stenelila } \\
\text { longirastris } \\
\text { (Lumba } \\
\text { spimmer) }\end{array}$ & $\mathrm{DD} /-$ & $99 \%$ & $\begin{array}{l}\text { Eastern } \\
\text { Tropical } \\
\text { Pacific } \\
\text { Ocean }\end{array}$ & $\begin{array}{l}\text { KX8574 } \\
10.1\end{array}$ \\
\hline 15 & $\begin{array}{l}\text { IBRCO42 } \\
\text { SO1 }\end{array}$ & $\begin{array}{l}\text { 3 Februari } \\
2016\end{array}$ & Ratna/Icha & - & $\begin{array}{l}\text { Pantai } \\
\text { Batu } \\
\text { Bolong, } \\
\text { Canggu, } \\
\text { Bali }\end{array}$ & $\begin{array}{l}\text { Paus } \\
\text { Bryde }\end{array}$ & - & & - & - & - \\
\hline 16 & $\begin{array}{l}\text { IBRCO42 } \\
601\end{array}$ & $\begin{array}{l}14 \text { Maret } \\
2016\end{array}$ & $\begin{array}{l}\text { Dio Maulid } \\
\text { Suhendro }\end{array}$ & - & $\begin{array}{l}\text { Pantai } \\
\text { Batu } \\
\text { Tumpeng, } \\
\text { Klungkun } \\
\text { g, Bali }\end{array}$ & - & - & & - & - & - \\
\hline 17 & $\begin{array}{l}\text { IBRCO42 } \\
{ }_{701} 04\end{array}$ & $\begin{array}{l}14 \text { Maret } \\
2016\end{array}$ & $\begin{array}{l}\text { Wira Sanjaya } \\
\text { (CTC) }\end{array}$ & + & $\begin{array}{l}\text { Pantai } \\
\text { Sampalan, } \\
\text { Nusa } \\
\text { Penida, } \\
\text { Bali }\end{array}$ & - & $\begin{array}{l}\text { Peponacepha } \\
\text { la electra } \\
\text { (Paus kepala } \\
\text { melon) }\end{array}$ & $\mathbf{L C} /-$ & $99 \%$ & $\begin{array}{l}\text { Ragoshi } \\
\text { ma, } \\
\text { Tanegas } \\
\text { hima, } \\
\text { Japan }\end{array}$ & $\begin{array}{l}\mathrm{AB} 6103 \\
\mathrm{~S} 7{ }_{1}\end{array}$ \\
\hline 18 & $\begin{array}{l}\text { IBRCO42 } \\
\text { SO1 }\end{array}$ & $\begin{array}{l}\text { 8 Agustus } \\
2015\end{array}$ & Dian (WWF) & - & $\begin{array}{l}\text { Buleleng, } \\
\text { pantai }\end{array}$ & - & - & & - & - & - \\
\hline 19 & $\begin{array}{l}\text { IBRCO42 } \\
901\end{array}$ & $\begin{array}{l}\text { 8 Agustus } \\
2015\end{array}$ & $\begin{array}{l}\text { I Made Jaya } \\
\text { Ratha }\end{array}$ & + & $\begin{array}{l}\text { Pantai } \\
\text { Kalibukbu } \\
\text { k, } \\
\text { Buleleng, } \\
\text { Bali }\end{array}$ & - & $\begin{array}{l}\text { Ziphizes } \\
\text { cavirostris } \\
\text { (Paus } \\
\text { moncong } \\
\text { Cuvier) }\end{array}$ & $\mathbf{L C} /-$ & $100 \%$ & - & $\begin{array}{l}\mathrm{KC} 7767 \\
17.1\end{array}$ \\
\hline 20 & $\begin{array}{l}\text { IBRCO43 } \\
\text { O01 }\end{array}$ & $\begin{array}{l}26 \text { Apri1 } \\
2016\end{array}$ & $\begin{array}{l}\text { Dwi Suprapti } \\
\text { (WWF) }\end{array}$ & + & $\begin{array}{l}\text { Paloh, } \\
\text { Kalimanta } \\
\text { n Barat }\end{array}$ & porpois & $\begin{array}{l}\text { Neophocaena } \\
\text { phocaenoides } \\
\text { (Porpoise } \\
\text { tanpa sirip) }\end{array}$ & $\begin{array}{l}\text { VU/CIT } \\
\text { ESII }\end{array}$ & $99 \%$ & $\begin{array}{l}\text { Northern } \\
\text { Yellow } \\
\text { Sea }\end{array}$ & $\begin{array}{l}\text { KR } 1083 \\
\text { O8.1 }\end{array}$ \\
\hline 21 & $\begin{array}{l}\text { IBRCO43 } \\
101\end{array}$ & $\begin{array}{l}26 \text { Apri1 } \\
2016\end{array}$ & $\begin{array}{l}\text { Dwi Suprapti } \\
\text { (WWF) }\end{array}$ & + & $\begin{array}{l}\text { Paloh, } \\
\text { Kalimanta } \\
\text { n Barat }\end{array}$ & porpois & $\begin{array}{l}\text { Neophocaenas } \\
\text { phocaenoides } \\
\text { (Porpoise } \\
\text { tampa sirip) }\end{array}$ & $\begin{array}{l}\mathrm{VU/CIT} \\
\mathrm{ES} I\end{array}$ & $99 \%$ & $\begin{array}{l}\text { Northern } \\
\text { Yellow } \\
\text { Sea }\end{array}$ & $\begin{array}{l}\text { KR } 1083 \\
\text { O8.1 }\end{array}$ \\
\hline 22 & $\begin{array}{l}\text { IBRCO } 0432 \\
01\end{array}$ & $\begin{array}{l}30 \text { Juni } \\
2016\end{array}$ & $\begin{array}{l}\text { Dwi Suprapti } \\
\text { (WWF) }\end{array}$ & + & $\begin{array}{l}\text { Proboling } \\
\text { go, Jawwa } \\
\text { Timul }\end{array}$ & $\begin{array}{l}\text { Paus } \\
\text { pilot } \\
\text { sirip } \\
\text { pendek }\end{array}$ & $\begin{array}{l}\text { Globicephala } \\
\text { macrorhynch } \\
\text { ws (Paus pilot } \\
\text { sirip pendek) }\end{array}$ & $\mathbf{D D} /-$ & $99 \%$ & $\begin{array}{l}\text { Hawaii, } \\
\text { USA }\end{array}$ & $\begin{array}{l}\text { JF33997 } \\
4.1\end{array}$ \\
\hline 23 & $\begin{array}{l}\text { IBRCO } 0433 \\
01\end{array}$ & $\begin{array}{l}30 \text { Juni } \\
2016\end{array}$ & $\begin{array}{l}\text { Dwi Suprapti } \\
\text { (WWF) }\end{array}$ & + & $\begin{array}{l}\text { Proboling } \\
\text { go, Jawa } \\
\text { Timur }\end{array}$ & $\begin{array}{l}\text { Paus } \\
\text { pilot } \\
\text { sirip } \\
\text { pendek }\end{array}$ & $\begin{array}{l}\text { Glabicephata } \\
\text { macrorhynch } \\
\text { us (Paus pilot } \\
\text { sirip pendek) }\end{array}$ & $\mathbf{D D} /-$ & $99 \%$ & $\begin{array}{l}\text { Hawaii, } \\
\text { USA }\end{array}$ & $\begin{array}{l}\text { JF33997 } \\
\text { H.1 }\end{array}$ \\
\hline 24 & $\begin{array}{l}\text { IBRCO } \\
\text { O1 }\end{array}$ & $\begin{array}{l}30 \text { Juni } \\
2016\end{array}$ & $\begin{array}{l}\text { Dwi Suprapti } \\
\text { (WWF) }\end{array}$ & + & $\begin{array}{l}\text { Proboling } \\
\text { go, Jawa } \\
\text { Timur }\end{array}$ & $\begin{array}{l}\text { Paus } \\
\text { pilot } \\
\text { sirip } \\
\text { pendek }\end{array}$ & $\begin{array}{l}\text { Globicephala } \\
\text { macrorhynch } \\
\text { ws (Paus pilot } \\
\text { sirip pendelc) }\end{array}$ & $\mathbf{D D} /-$ & $99 \%$ & $\begin{array}{l}\text { Hawaii, } \\
\text { USA }\end{array}$ & $\begin{array}{l}\text { JF } 33997 \\
4.1\end{array}$ \\
\hline
\end{tabular}


Identifikasi Jenis pada Kejadian Cetacea Terdampar di Indonesia dengan ...

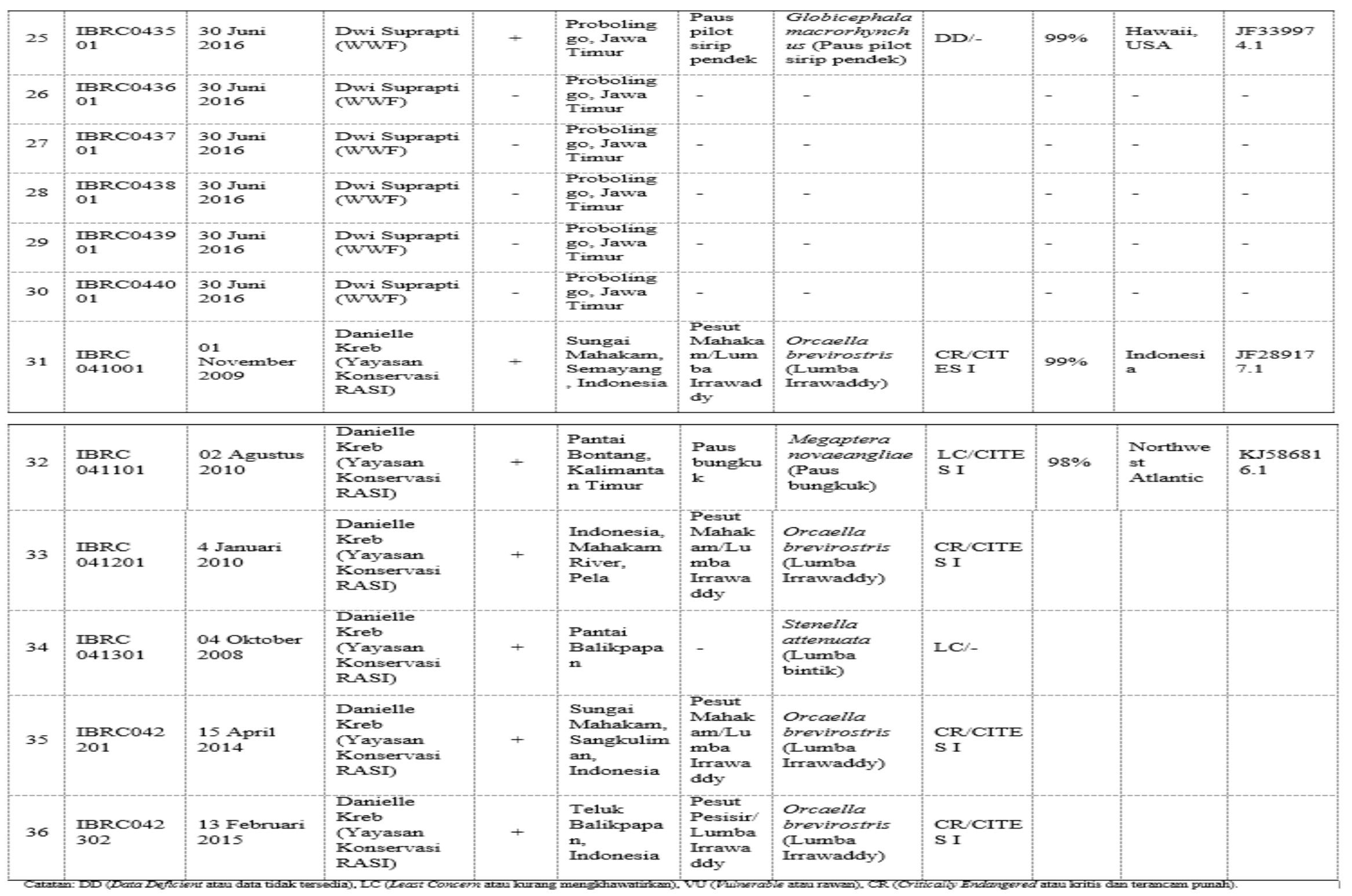

